\title{
Comparative Phytochemical Profiling and In Vitro Antioxidant Activity of Extracts from Raw Materials, Tissue-Cultured Plants, and Callus of Oroxylum indicum (L.) Vent.
}

\author{
Piyanuch Rojsanga, ${ }^{1}$ Somnuk Bunsupa, ${ }^{2}$ Adelheid H. Brantner, ${ }^{3}$ and Pongtip Sithisarn ${ }^{2}$ \\ ${ }^{1}$ Department of Pharmaceutical Chemistry, Faculty of Pharmacy, Mahidol University, Bangkok 10400, Thailand \\ ${ }^{2}$ Department of Pharmacognosy, Faculty of Pharmacy, Mahidol University, Bangkok 10400, Thailand \\ ${ }^{3}$ Institute of Pharmaceutical Sciences, Pharmacognosy, University of Graz, 8010 Graz, Austria \\ Correspondence should be addressed to Pongtip Sithisarn; pongtip.sit@mahidol.ac.th
}

Received 11 July 2017; Accepted 13 September 2017; Published 31 October 2017

Academic Editor: Nunziatina De Tommasi

Copyright (C) 2017 Piyanuch Rojsanga et al. This is an open access article distributed under the Creative Commons Attribution License, which permits unrestricted use, distribution, and reproduction in any medium, provided the original work is properly cited.

\begin{abstract}
Extracts from raw materials from different plant parts, tissue-cultured plants, and callus cultures of Oroxylum indicum were analyzed for in vitro antioxidant activities determined by DPPH radical scavenging assay and evaluated for phytochemical profiles by TLC and LC-MS methods. The results were analyzed by principal component analysis (PCA) to evaluate the similarity. Stalk, pedicel, flower, seed, and whole fruit and callus extracts promoted strong antioxidant activity with high total phenolic and total flavonoid contents. The main phytochemicals found in extracts were baicalin, baicalein, and chrysin. Baicalein and baicalin promoted strong antioxidant effects and existed in most extracts while chrysin, which promoted very low antioxidant activity, was a major flavonoid in the leaves and tissue-cultured plants. From PCA analysis by total phenolic and total flavonoid contents, four main clusters including callus and tissue-cultured plant groups from different growth stages, flower group, and whole fruit and leaf group could be organized. When the results were analyzed by PCA using antioxidant activity with total phenolic or total flavonoid contents, all O. indicum samples could be grouped together except the extracts from the root of tissue-cultured plants which separated from the rest due to their low phytochemical contents and weak antioxidant activities.
\end{abstract}

\section{Introduction}

Oroxylum indicum (L.) Vent. is a medium-sized, deciduous tree of the Bignoniaceae family. The tree has very large pinnate compound leaves. The outside petals are reddish purple with the pale yellow inside. Fruits are flat capsules, broad and sword shaped [1]. The seeds are numerous, flat-like papery wings [2]. Mature fruit is acrid and sweet, which promotes antihelminthic and stomachic effects [3]. The seeds have been used as purgative while the seed paste is applied to the throat for quick relief of tonsil pain $[1,2]$. Our previous study reported the in vitro antibacterial and antioxidant activities of $O$. indicum fruit extracts [4]. Furthermore, the young fruits and young flowers of this plant are popularly consumed as vegetable in the North of Thailand while the mature seeds are one composition in a traditional multiherb drink for the treatment of aphthous ulcer and sore throat. Some phytochemicals were reported from different parts of $O$. indicum such as flavonoids, anthraquinones, alkaloids, saponins, and fatty acids [4-7]. Despite every part of $O$. indicum being useful for both nutritional and medicinal applications, however, the source of $O$. indicum raw materials seems to be limited. Moreover, it takes some times for this plant to fully grow as a tree for its appropriate uses. Therefore, finding the methods to increase and develop new sources of plant raw material would be beneficial in the future. Plant tissue culture technique is widely used in the conservation and utilization of rare and endangered medicinal plants due to its remarkable ability of quickly increasing their biomass $[8,9]$.

To our knowledge, no documents have ever been published about phytochemical profiles and antioxidant activities 
of the raw materials from different plant parts, tissue-cultured plants, and callus by chromatographic and spectrophotometric methods. This study provides the information of in vitro free radical scavenging effects tested by the DPPH assay, TLC and LC-MS fingerprints, and total phenolic and total flavonoid contents of extracts from $O$. indicum from different sources including flowers, leaves and fruits raw materials, tissue-cultured plants from different growth stages, and callus. The obtained results were also analyzed for similarity by principal component analysis (PCA).

\section{Materials and Methods}

\subsection{Materials}

\subsubsection{Plant Material Preparations}

(1) Raw Materials from Different Plant Parts. The flowers (3 growth stages), pedicels, leaves, and stalks of $O$. indicum were collected from Bangkok province. The fruits for preparation of fruit and callus extracts were purchased from Chiang Rai province, while the seeds for preparation of tissue-cultures plants were purchased from Pattani province, Thailand, in 2016. Plant samples were identified by Assistant Professor Dr. Pongtip Sithisarn, Department of Pharmacognosy, Faculty of Pharmacy, Mahidol University, Thailand. The plant samples were separately cleaned and dried in a hot air oven at $60^{\circ} \mathrm{C}$ and then ground using an electric mill.

(2) Tissue-Cultured Plants (In Vitro Plants). The seeds of O. indicum were cleaned using detergent and tap water flow for $15 \mathrm{~min}$. Then they were sterilized by soaking in $70 \%$ ethanol for $30 \mathrm{sec}$ followed by soaking in 1\% sodium hypochlorite for $7 \mathrm{~min}$. The sterilized seeds were washed by shaking in deionized water for $1 \mathrm{~min}$, repeated for 5 times. Then the wings of the seeds were removed and the seeds were placed on sterilized MS (Murashige and Skoog) media (pH 5.8, 3\% sucrose and 0.8\% agar) [10]. Each media bottle contained 3 seeds of $O$. indicum. The bottles were kept in the dark until week 5 to induce germination and then they were moved to store under the photoperiod of $16 / 8 \mathrm{~h}$ (light/dark) until week 8. Plant samples were randomized using True Random Number Service software (Randomness and Integrity Services Ltd., Ireland) at days 3, 5, and 7 and then weekly from week 2 to week 8 . Plant samples were cleaned and dried in a hot air oven at $60^{\circ} \mathrm{C}$ then ground using an electric mill. Plant samples from week 5 to week 8 were separated for the aerial and root parts before they were cleaned and dried.

(3) Callus. The seeds of O. indicum were separated from the fruits from Chiang Rai province and then they were washed with tap water for $15 \mathrm{~min}$ before sterilization with $70 \%$ ethanol for 1 minute. After that, the seeds were further sterile with $1 \%$ sodium hypochlorite for 8 minutes and then washed with sterile distilled water ( 5 times) to remove the remaining sterilization reagents. After the sterilization process, the wing part of the seeds was cut with sterile scissors in a laminar cabinet and the seeds then were placed in MS media supplemented with $3 \%$ sucrose and $0.8 \%$ agar before being stored in a dark place to induce the germination. After seven days, the germinated in vitro plants were moved to store under the photoperiod of 16/8 h (light/dark).

The in vitro plants were collected after 8 weeks of cultivation and excised to explants $(2-3 \mathrm{~cm}$ long/piece). The explants were inoculated in MS media supplemented with $3 \%$ sucrose, $0.8 \%$ agar, $2 \mathrm{mg} / \mathrm{L}$ of 2,4-dichlorophenoxy acetic acid $(2,4-\mathrm{D})$, and $1 \mathrm{mg} / \mathrm{l}$ of 6 -benzyladenine (BA). After 21 days, the induced callus was cut from the explants and cultured into the mentioned media and then subcultured every 21 days for three more times. After that, the callus was cultured to 28 days before being collected, dried, and then grinded to powder. The powdered callus was subjected for the further extraction process. Figure 1 shows physical characteristics of $O$. indicum samples.

\subsection{Methods}

2.2.1. Plant Extract Preparation. Each O. indicum sample was separately extracted by maceration using $95 \%$ ethanol (plant: solvent ratio 1:20 w/v) with continuous shaking for $6 \mathrm{~h}$; then it was left for $12 \mathrm{~h}$ [4]. After that, the solution was filtered. Each extraction was repeated three times. The extracts were then combined and dried using a water bath.

2.2.2. Determination of Antioxidant Activity by DPPH Scavenging Assay. The free radical scavenging activity of extracts from $O$. indicum sample was investigated using the 1,1-diphenyl-2-picrylhydrazyl (DPPH) radical scavenging method [11]. A total of $100 \mu \mathrm{L}$ of the extract or standard was added to $100 \mu \mathrm{L}$ of DPPH in a methanolic solution $(152 \mu \mathrm{M})$. After staying at room temperature for $15 \mathrm{~min}$, the absorbance of each solution was determined at $515 \mathrm{~nm}$ using a microplate reader (Tecan, USA). The percentage of inhibition was calculated. Then the $\mathrm{EC}_{50}$ value of the samples required for $50 \%$ scavenging of the DPPH free radical was determined. Each determination was done in triplicate, and the average $\mathrm{EC}_{50}$ value was calculated.

\subsubsection{Phytochemical Studies}

(1) Determination of Total Phenolic Content Using FolinCiocalteu Method. Plant extract solutions $(25 \mu \mathrm{L})$ were oxidized with Folin-Ciocalteu reagent $(25 \mu \mathrm{L})$ in 96-well plate. $75 \mu \mathrm{L}$ of distilled water and $100 \mu \mathrm{L}$ of $20 \%$ sodium carbonate solution were added. The absorbance of the resulting blue colored solution was measured at $765 \mathrm{~nm}$ after $60 \mathrm{~min}$ using a Microplate Reader (Tecan, USA) [12]. Each sample was done in triplicate. Total phenolic content was calculated from the standard curve of gallic acid and was expressed as g gallic acid equivalent in $100 \mathrm{~g}$ extract ( $\mathrm{g} \% \mathrm{GAE}$ ).

(2) Determination of the Total Flavonoid Content. Plant sample solutions $(100 \mu \mathrm{L})$ were separately reacted with a $2 \%$ aluminium chloride solution in the same volume. The absorbance was measured at $415 \mathrm{~nm}$ after $10 \mathrm{~min}$ using a Microplate Reader (Tecan, USA) [13]. Flavonoid content was calculated with the standard curve of quercetin and was 

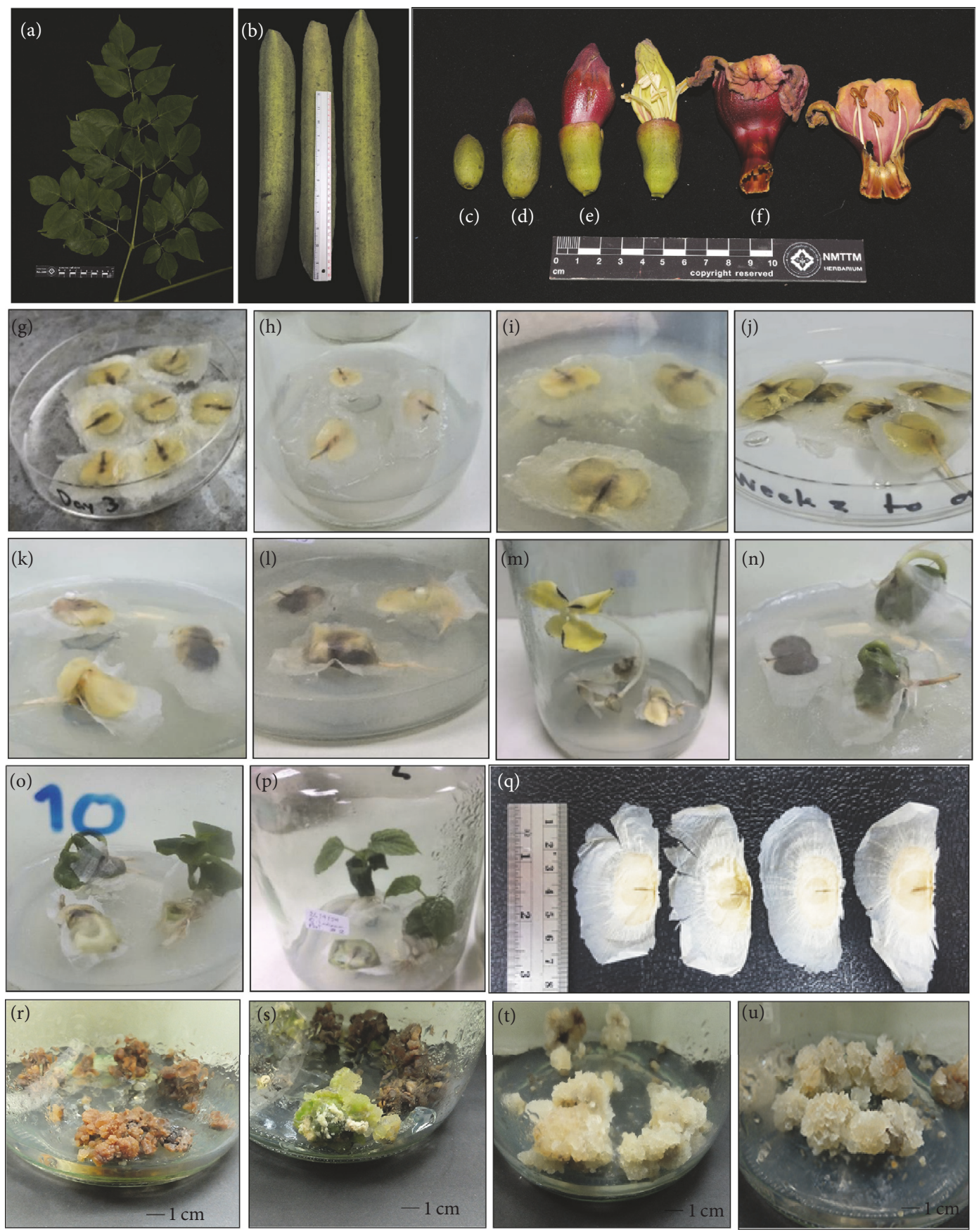

Figure 1: Physical characteristics of Oroxylum indicum samples. $(a)=$ leaves, $(\mathrm{b})=$ whole fruit, $(\mathrm{c})=$ flower $($ stage 1$)$, (d) = flower (stage 2), (e) = flower (stage 3), (f) = flower (bloom), (g) = tissue-cultured plant (day 3), (h) = tissue-cultured plant (day 5), (i) = tissue-cultured plant $($ day 7$),(\mathrm{j})=$ tissue-cultured plant (week 2$),(\mathrm{k})=$ tissue-cultured plant (week 3$),(\mathrm{l})=$ tissue-cultured plant $($ week 4$),(\mathrm{m})=$ tissue-cultured plant (week 5), (n) = tissue-cultured plant (week 6), (o) = tissue-cultured plant (week 7), (p) = tissue-cultured plant (week 8), (q) = mature seed, $(\mathrm{r})=$ brown callus, $(\mathrm{s})=$ green callus, $(\mathrm{t})=$ white callus, and $(\mathrm{u})=$ yellow callus .

expressed as g quercetin equivalent in $100 \mathrm{mg}$ of plant extracts (g\% QE).

(3) Thin Layer Chromatographic (TLC) Fingerprints. O. indicum extracts were spotted on precoated silica gel 60 GF254 TLC plates. The plates were developed in two solvent systems, which were solvent system A: ethyl acetate:glacial acetic acid : formic acid : hexane $(5: 1: 1: 5, v / v / v / v)$ and solvent system B: ethyl acetate : toluene : formic acid $(25: 25: 7.5, v / v / v)$. The developing distance was $85 \mathrm{~mm}$. After being removed from the developing chamber, the TLC plates were air dried in a fume hood and examined under UV light at wavelengths of 254 and $366 \mathrm{~nm}$ and under UV light at a wavelength of $366 \mathrm{~nm}$ after spraying with natural products/polyethylene 
glycol (NP/PEG) reagent [4]. The TLC fingerprints of $O$. indicum extracts were recorded.

(4) Ultrahigh Performance Liquid Chromatographic-Mass Spectrometry (LC-MS) Fingerprints. LC-MS analysis of all extracts from $O$. indicum was conducted using the method applied from Krüger and Ganzera [14] with Ultimate 3000 machine equipped with photodiode array and mass spectrometry detectors. A Kinetex C18 column $(2.10 \mathrm{~mm}$ i.d. $\times$ $10 \mathrm{~cm}, 2.6 \mu \mathrm{m}$ ) was used for quantitative analysis. Gradient elution was performed with $0.1 \%$ formic acid in water (solvent A) and acetonitrile (solvent B) at a constant flow rate of $0.35 \mathrm{~mL} / \mathrm{min}$. The gradient program was adjusted from $30 \%$ to $90 \%$ B in $10 \mathrm{~min}$ and stayed at $90 \%$ B for $2 \mathrm{~min}$. Then the gradient program was adjusted to $30 \% \mathrm{~B}$ and stayed at $30 \% \mathrm{~B}$ for $3 \mathrm{~min}$. Column temperature was $30^{\circ} \mathrm{C}$ with an injection volume of $3 \mu \mathrm{L}$. Injection concentrations of standard references and plant samples were 10 and $100 \mu \mathrm{g} / \mathrm{mL}$, respectively. UV detection was also performed at $280 \mathrm{~nm}$.

2.2.4. Principal Component Analysis (PCA). Data sets of $\mathrm{DPPH}$ scavenging activities ( $\mathrm{EC}_{50}$ values), total phenolic, and total flavonoid contents of extracts from different plant parts and growth stages of $O$. indicum were subjected to Principal Component Analysis (PCA) using Minitab ${ }^{\circledR}$ (Minitab Pty Ltd., Australia).

2.2.5. Statistical Analysis. All data are reported as means \pm standard deviation of triplicate analysis. Least significant difference was used to compare means $(p<0.05)$. All analyses were performed using SPSS for Windows, version 16.0 (SPSS Inc., USA).

\section{Results and Discussion}

3.1. Physical Characteristics of Tissue-Cultured Plants. The physical characteristics of tissue-cultured plants are shown in Figure 1. From the starting day to day 7 of growing, there was no apparent change in physical characteristics of $O$. indicum seeds (Figures $1(\mathrm{~g})-1(\mathrm{i})$ ). In weeks 2 and 3 , the roots started to appear, elongate, and root into the media (Figures 1(j) and $1(\mathrm{k}))$. In week 4 , the length of the roots was about $3-5 \mathrm{~cm}$ (Figure 1(1)). The stems of $O$. indicum developed out of the seeds in week 5 and the stem length was about $6-8 \mathrm{~cm}$ with the light yellow cotyledons (Figure $1(\mathrm{~m})$ ). After the tissuecultured plants were placed under the photoperiod of $16 / 8 \mathrm{hr}$ light/dark condition, the color of the cotyledons changed from light yellow to green in week 6 (Figure 1(n)). The leaves started to grow in week 7 and clearly developed in week 8 with the length of the leaves around $3 \mathrm{~cm}$; the stem was strong with the root length around $10 \mathrm{~cm}$ (Figures $1(\mathrm{o})$ and $1(\mathrm{p})$ ).

3.2. Physical Characteristics of Oroxylum indicum Callus. The 28 -day calluses from the leaves of $O$. indicum in vitro plants (8 weeks old) in MS media supplemented with $3 \%$ sucrose, $0.8 \%$ agar, $2 \mathrm{mg} / \mathrm{L}$ of 2,4-D, and $1 \mathrm{mg} / \mathrm{l}$ of BA can be divided into 4 types of samples: brown, green, white, and yellow calluses as shown in Figures 1(r) $-1(\mathrm{u})$, respectively.
3.3. Physical Characteristics of Oroxylum indicum Extracts. The extracts from various parts of O. indicum (OI) including the seeds (OIMS), whole fruits (OIWF), flower stage 1 (OIFL1), flower stage 2 (OIFL2), flower stage 3 (OIFL3), flower stage 4 (OIFL4), leaves (OIL), pedicel (OIPC), stalk (OIS), tissue-cultured plant day 3 (OITPd3), tissue-cultured plant day 5 (OITPd5), tissue-cultured plant day 7 (OITPd7), tissue-cultured plant week 2 (OITPw2), tissue-cultured plant week 3 (OITPw3), tissue-cultured plant week 4 (OITPw4), the root of tissue-cultured plant week 5 (OITPw5R), the shoot of tissue-cultured plant week 5 (OITPw5S), the root of tissue-cultured plant week 6 (OITPw6R), the shoot of tissuecultured plant week 6 (OITPw6S), the root of tissue-cultured plant week 7 (OITPw7R), the shoot of tissue-cultured plant week 7 (OITPw7S), the root of tissue-cultured plant week 8 (OITPw8R), the shoot of tissue-cultured plant week 8 (OITPw8S), brown callus (OICB), green callus (OICG), yellow callus (OICY), and white callus (OICW) appeared as brown semisolid matters with the yields shown in Table 1.

3.4. Determination of the Antioxidant Activity of Oroxylum indicum Extracts. The free radical scavenging activity of O. indicum extracts and of standard ascorbic acid, baicalin (Pharmaceutical grade, TRC, Canada), baicalein (analytical reference grade, Sigma-Aldrich, USA), and chrysin (Pharmaceutical grade, TRC, Canada), was investigated using the DPPH radical scavenging method (Table 1). Ascorbic acid, baicalein, and baicalin promoted strong antioxidant activities $\left(\mathrm{EC}_{50}\right.$ values of $5.10,8.98$ and $32.49 \mu \mathrm{g} / \mathrm{mL}$, resp.) while chrysin showed low antioxidant effect $\left(\mathrm{EC}_{50}\right.$ values higher than $500 \mu \mathrm{g} / \mathrm{mL}$ ). Extracts from O. indicum exhibited antioxidant activity varying from weak to strong effects. The mature seed (OIMS) and whole fruit (OIWF) extracts showed similar good antioxidant effects $\left(\mathrm{EC}_{50}\right.$ values of 73.81 and $65.89 \mu \mathrm{g} / \mathrm{mL}$, resp.). Oroxylum indicum flower extracts indicated moderate to high antioxidant activity $\left(\mathrm{EC}_{50}\right.$ values in the range of 26 to $85 \mu \mathrm{g} / \mathrm{mL}$ ). The bud (OIFL1) and the blossom flower (flower stage 4 , OIFL4) extracts revealed very strong antioxidant effects $\left(\mathrm{EC}_{50}\right.$ values of 48.14 and $26.04 \mu \mathrm{g} / \mathrm{mL}$, resp.) while the bud stage 2 (OIFL2) and bud stage 3 (OIFL3) demonstrated a lower activity $\left(\mathrm{EC}_{50}\right.$ values of 71.69 and $84.64 \mu \mathrm{g} / \mathrm{mL}$, resp.). Pedicel (OIPC), stalk (OIS), and leaf (OIL) extracts also promoted strong antioxidant effects $\left(\mathrm{EC}_{50}\right.$ values in the range of 17 to $\left.65 \mu \mathrm{g} / \mathrm{mL}\right)$. Most of tissue-cultured plant extracts exhibited weak DPPH scavenging effects $\left(\mathrm{EC}_{50}\right.$ values in the range of 68 to $610 \mu \mathrm{g} / \mathrm{mL})$. In the early stages of the tissue culture of day 3-week 2 (OITPd3-OITPw2), the extracts showed moderate to low antioxidant effects $\left(\mathrm{EC}_{50}\right.$ values in the range of 68 to $165 \mu \mathrm{g} / \mathrm{mL}$ ), which decreased significantly following the growth stages of the tissue-cultured plants. During week 3-week 7, the tissue-cultured plant extracts (OITPw3-OITPw7) exhibited low antioxidant activities $\left(\mathrm{EC}_{50}>100 \mu \mathrm{g} / \mathrm{mL}\right)$. The root extracts showed weaker antioxidant effects than those from the shoots. However, the antioxidant activity of the shoot extract from tissue-cultured plant at week 8 (OITPw8S) was noticeably risen again to the moderate level; this may suggest the change of biosynthesis of the secondary metabolite in $\mathrm{O}$. indicum plant culture at 
TABLE 1: Total phenolic and total flavonoid contents and in vitro antioxidant activity of extracts from various parts and different growth stages of $O$. indicum.

\begin{tabular}{|c|c|c|c|c|}
\hline Sample & Yield (\% w/w) & $\begin{array}{l}\text { Total phenolic content } \\
\text { (g GAE/100 g extract) }\end{array}$ & $\begin{array}{l}\text { Total flavonoid content } \\
\text { (g QE/100 g extract) }\end{array}$ & $\begin{array}{l}\text { Antioxidant activity } \\
\left(\mathrm{EC}_{50}, \mu \mathrm{g} / \mathrm{mL}\right)\end{array}$ \\
\hline OIMS & 17.54 & $7.31 \pm 0.92^{\mathrm{a}, \mathrm{b}}$ & $5.31 \pm 0.73^{\mathrm{a}, \mathrm{b}}$ & $73.81 \pm 1.89^{\mathrm{a}}$ \\
\hline OIWF & 26.11 & $4.57 \pm 0.45^{\mathrm{c}, \mathrm{d}}$ & $4.68 \pm 0.12^{\mathrm{b}}$ & $65.89 \pm 5.48^{\mathrm{a}, \mathrm{b}, \mathrm{c}}$ \\
\hline OIFL1 & 16.12 & $6.30 \pm 0.46^{\mathrm{a}, \mathrm{e}, \mathrm{f}, \mathrm{g}}$ & $5.83 \pm 0.28^{\mathrm{a}}$ & $48.14 \pm 0.92^{\mathrm{d}}$ \\
\hline OIFL2 & 15.46 & $2.15 \pm 0.24^{\mathrm{h}}$ & $3.58 \pm 0.17^{c}$ & $71.69 \pm 3.01^{\mathrm{a}, \mathrm{e}}$ \\
\hline OIFL3 & 39.91 & $2.97 \pm 0.31^{\mathrm{i}, \mathrm{j}}$ & $3.33 \pm 0.10^{c}$ & $84.64 \pm 2.49^{f}$ \\
\hline OIFL4 & 30.52 & $2.63 \pm 0.33^{\mathrm{i}, \mathrm{k}, \mathrm{l}}$ & $2.41 \pm 0.04^{\mathrm{d}}$ & $26.04 \pm 0.59^{g}$ \\
\hline OIL & 22.02 & $4.10 \pm 0.70^{\mathrm{d}, \mathrm{j}, \mathrm{m}}$ & $4.59 \pm 0.32^{\mathrm{b}}$ & $63.21 \pm 4.79^{\mathrm{b}, \mathrm{c}}$ \\
\hline OIPC & 11.10 & $5.66 \pm 0.45^{\mathrm{f}, \mathrm{g}}$ & $3.24 \pm 0.18^{\mathrm{c}}$ & $23.66 \pm 1.47^{\mathrm{g}}$ \\
\hline OIS & 11.63 & $2.31 \pm 0.22^{\mathrm{h}, \mathrm{k}, 1}$ & $3.32 \pm 0.10^{c}$ & $17.69 \pm 1.55^{\mathrm{h}}$ \\
\hline OITPd3 & 17.80 & $2.74 \pm 0.59^{\mathrm{h}, \mathrm{I}, \mathrm{j}, \mathrm{k}, \mathrm{l}}$ & $1.25 \pm 0.08^{\mathrm{e}}$ & $162.38 \pm 6.34^{\mathrm{i}}$ \\
\hline OITPd5 & 18.53 & $7.79 \pm 1.02^{\mathrm{a}, \mathrm{b}}$ & $2.30 \pm 0.21^{\mathrm{d}, \mathrm{f}}$ & $69.61 \pm 2.67^{\mathrm{a}, \mathrm{c}, \mathrm{e}}$ \\
\hline OITPd7 & 25.34 & $7.19 \pm 0.85^{\mathrm{a}, \mathrm{b}, \mathrm{e}, \mathrm{g}, \mathrm{n}}$ & $2.80 \pm 0.17^{\mathrm{g}}$ & $68.96 \pm 0.36^{\mathrm{c}, \mathrm{e}}$ \\
\hline OITPw2 & 27.83 & $6.01 \pm 0.29^{\mathrm{b}, \mathrm{f}, \mathrm{n}}$ & $2.34 \pm 0.12^{\mathrm{d}}$ & $95.03 \pm 1.06^{j}$ \\
\hline OITPw3 & 31.73 & $5.50 \pm 0.46^{\mathrm{e}, \mathrm{f}}$ & $0.94 \pm 0.24^{\mathrm{e}, \mathrm{h}}$ & $119.42 \pm 3.08^{\mathrm{k}}$ \\
\hline OITPw4 & 31.47 & $1.93 \pm 0.54^{\mathrm{h}, \mathrm{k}, \mathrm{l}, \mathrm{o}, \mathrm{p}}$ & $0.73 \pm 0.08^{h}$ & $156.97 \pm 4.16^{\mathrm{i}}$ \\
\hline OITPw5R & 10.38 & $0.74 \pm 0.14^{\circ}$ & $0.19 \pm 0.06^{\mathrm{i}}$ & $500.98 \pm 12.25^{1}$ \\
\hline OITPw5S & 24.55 & $3.82 \pm 0.18^{\mathrm{d}}$ & $1.30 \pm 0.11^{\mathrm{e}}$ & $117.49 \pm 19.81^{\mathrm{j}, \mathrm{k}}$ \\
\hline OITPw6R & 18.90 & $1.17 \pm 0.05^{\mathrm{p}, \mathrm{q}}$ & Cannot be detected & $435.21 \pm 2.30^{\mathrm{m}}$ \\
\hline OITPw6S & 19.17 & $2.72 \pm 0.35^{\mathrm{i}, \mathrm{k}, 1}$ & $1.26 \pm 0.11^{\mathrm{e}}$ & $205.60 \pm 2.25^{\mathrm{n}}$ \\
\hline OITPw7R & 16.11 & $2.43 \pm 0.52^{\mathrm{i}, \mathrm{k}, 1}$ & Cannot be detected & $454.36 \pm 9.15^{\circ}$ \\
\hline OITPw7S & 18.45 & $2.67 \pm 0.14^{\mathrm{i}, \mathrm{j}, 1}$ & $0.03 \pm 0.00^{j}$ & $251.63 \pm 2.95^{\mathrm{p}}$ \\
\hline OITPw8R & 19.10 & $1.44 \pm 0.08^{\mathrm{r}}$ & Cannot be detected & $607.57 \pm 4.52^{\mathrm{q}}$ \\
\hline OITPw8s & 20.12 & $1.72 \pm 0.40^{\mathrm{h}, \mathrm{q}, \mathrm{r}}$ & $2.32 \pm 0.27^{\mathrm{d}}$ & $85.19 \pm 2.39^{f}$ \\
\hline OICB & 25.12 & $6.90 \pm 0.45^{\mathrm{a}}$ & $2.73 \pm 0.03^{\mathrm{g}, \mathrm{k}}$ & $38.78 \pm 1.32^{\mathrm{r}}$ \\
\hline OICG & 26.83 & $5.09 \pm 1.00^{\mathrm{d}, \mathrm{e}, \mathrm{f}, \mathrm{g}, \mathrm{m}}$ & $2.66 \pm 0.07^{\mathrm{g}, \mathrm{k}}$ & $98.55 \pm 1.92^{j}$ \\
\hline OICW & 27.30 & $7.05 \pm 0.90^{\mathrm{a}, \mathrm{b}, \mathrm{f}, \mathrm{g}}$ & $2.61 \pm 0.06^{\mathrm{f}, \mathrm{g}}$ & $63.62 \pm 3.32^{\mathrm{b}, \mathrm{c}}$ \\
\hline OICY & 24.64 & $6.41 \pm 0.91^{\mathrm{a}, \mathrm{b}, \mathrm{f}, \mathrm{g}}$ & $2.63 \pm 0.03^{\mathrm{f}, \mathrm{g}}$ & $58.64 \pm 2.59^{\mathrm{b}}$ \\
\hline Ascorbic acid & - & - & - & $5.10 \pm 0.57$ \\
\hline Chrysin & - & - & - & $>500$ \\
\hline Baicalein & - & - & - & $8.98 \pm 0.86$ \\
\hline Baicalin & - & - & - & $32.49 \pm 12.52$ \\
\hline
\end{tabular}

Different letters in the same column are significantly different $(p<0.05)$; OIMS $=$ OI seed extract, OIWF $=$ OI whole fruit extract, OIFL1 $=$ OI flower stage 1 extract, OIFL $2=$ OI flower stage 2 extract, OIFL3 $=$ OI flower stage 3 extract, OIFL $4=$ OI flower stage 4 extract, OIL $=$ OI leaf extract, OIPC $=$ OI pedicel extract, OIS $=$ OI stalk extract, OITPd $3=$ OI tissue-cultured plant day 3 extract, OITPd $5=$ OI tissue-cultured plant day 5 extract, OITPd $7=$ OI tissue-cultured plant day 7 extract, OITPw2 $=$ OI tissue-cultured plant week 2 extract, OITPw $3=$ OI tissue-cultured plant week 3 extract, OITPw $4=$ OI tissue-cultured plant week 4 extract, OITPw5R $=$ OI tissue-cultured plant week 5 root extract, OITPw5S $=$ OI tissue-cultured plant week 5 shoot extract, OITPw6R $=$ OI tissue-cultured plant week 6 root extract, OITPw6S $=$ OI tissue-cultured plant week 6 shoot extract, OITPw7R = OI tissue-cultured plant week 7 root extract, OITPw7S $=$ OI tissue-cultured plant week 7 shoot extract, OITPw8R $=$ OI tissue-cultured plant week 8 root extract, OITPw8S $=$ OI tissue-cultured plant week 8 shoot extract, $\mathrm{OICB}=\mathrm{OI}$ brown callus extract, $\mathrm{OICG}=\mathrm{OI}$ green callus extract, $\mathrm{OICY}=\mathrm{OI}$ yellow callus extract, and OICW $=$ OI white callus extract. 
this growth stage. Interestingly, all extracts from different colors of callus cultures (OIC) of O. indicum exhibited strong DPPH scavenging effects. The brown callus culture (OICB) significantly showed the highest antioxidant effect.

\subsection{Phytochemical Study of Oroxylum indicum Extracts}

3.5.1. Determination of Total Phenolic and Total Flavonoid Contents by Spectrophotometric Techniques. Extract from various parts of $O$. indicum were quantitatively analyzed for total phenolic and total flavonoid contents using FolinCiocalteu and aluminium chloride methods, respectively. Phenolic and flavonoid contents were significantly responsible for the DPPH scavenging effects of $O$. indicum extracts. As shown in Table 1, extracts that promoted strong antioxidant effects including flower stage 1 (OIFL1), mature seed (OIMS), whole fruit (OIWF), pedicel (OIPC), and leaf (OIL) extracts contained high amounts of total phenolic compounds and total flavonoids (higher than $4 \mathrm{~g} \% \mathrm{GAE}$ and $3 \mathrm{~g} \% \mathrm{QE}$, resp.). Extracts from tissue-cultured plants in early stages (OITPd5, OITPd7, OITPw2, and OTPw3) and callus cultures (OICB, OICG, OICW, and OICY) promoted the similar trends of high total phenolic contents (higher than $5 \mathrm{~g} \% \mathrm{GAE}$ ) with moderate amounts of total flavonoids (around 1-2 g\% QE). The stalk extract (OIS) promoted the highest antioxidant activity. However, the total phenolic and total flavonoid contents in this extract are in moderate level $(2 \mathrm{~g} \%$ GAE and $3 \mathrm{~g} \% \mathrm{QE}$, resp.) suggesting the presence of other phytochemicals that support the antioxidant effects such as tannin and ascorbic acid. The late stages of tissue-cultured plants (OITPw4-OITPw8) promoted extracts with low to moderate phenolic and flavonoid contents (1-4 g\% GAE and cannot be detected $-3 \mathrm{~g} \% \mathrm{RE}$, resp.) corresponding to their weak antioxidant effects. The results suggest that in $O$. indicum tissuecultured plants, phenolic compounds, especially flavonoids, are stored mainly in shoot, but the amounts of them are very low in the root (lower than $1 \mathrm{~g} \% \mathrm{QE}$ ).

3.5.2. TLC Fingerprints of Oroxylum indicum Extracts. Thin layer chromatographic fingerprints of extracts from different plant parts and growth stages of $O$. indicum were phytochemically analyzed using 2 different solvent systems and detected under UV lights and NP/PEG spraying reagent. All extracts promoted specific chromatographic characteristics with the presence of phenolic and flavonoid compounds and extracts from the same plant parts promoted similar fingerprints as shown in Figure 2. Baicalein and chrysin ( Rf 0.64 and 0.71 in solvent system $A$ and 0.60 and 0.70 in solvent system B, resp.) showed the same trend in the extracts from the fruits, seeds, flowers, pedicels, and stalks of O. indicum. Their amounts are high in early stages of flowers (OIFL1 and OIFL2) but the amounts are decreasing in late stage flowers (OIFL3 and OIFL4), pedicel (OIPC) and stalk (OIS) extracts. Notably, in the leaf (OIL) and the tissue-cultured plant (OITP) extracts, chrysin was the major flavonoid. The results suggest that chrysin was biosynthesized and stored in the leaf part of $O$. indicum higher than other flavonoids. The amount of baicalin (Rf 0.06 and 0.02 in solvent system A and B, resp.) was quite low in all extracts. The extracts from callus cultures
(OIC) slightly showed the bands corresponding baicalein and chrysin, but they mainly showed the chromatographic bands corresponded to phenolic compounds which appeared as bright blue bands after spraying with NP/PEG and detecting under UV $366 \mathrm{~nm}$. The flower stage 1 (OIFL1), flower stage 4 (OIFL4), pedicel (OIPC), stalk (OIS), and brown callus (OICB) extracts, which promoted strong antioxidant effects, did not mainly show baicalein, baicalin, or chrysin bands while the tissue-cultured plant and leaf extracts contained mainly chrysin and promoted lower antioxidant effect. The results suggest that baicalein, chrysin, and baicalin are three main components in O. indicum and also exhibit an antioxidant effect. There should be other phenolics and flavonoids that are responsible for the antioxidant activity of this plant. This suggestion was supported by the TLC fingerprints that showed some other chromatographic bands reacting positive after spraying with NP/PEG reagent indicating that they should be phenolics and/or flavonoids.

3.5.3. LC-MS Fingerprints of Oroxylum indicum Extracts. LC-MS was used to analyze and identify the peaks of the standards baicalin, baicalein, and chrysin. It was found that baicalin promoted the LC-MS peak at a retention time of 1.41 minutes with UV spectra at the maximum wavelength of 216,280 , and $318 \mathrm{~nm}$ and molecular mass (negative mode) of $445 \mathrm{~m} / z$. Baicalein promoted the LC-MS peak at a retention time of 3.15 minutes with UV spectra at the maximum wavelength of 218, 278, and $324 \mathrm{~nm}$ and molecular mass (negative mode) of $269 \mathrm{~m} / z$. Chrysin promoted the LC-MS peak at a retention time of 4.40 minutes with UV spectra at the maximum wavelength of 214, 270, and $315 \mathrm{~nm}$ and molecular mass (negative mode) of $253 \mathrm{~m} / z$. Different plant parts and growth stages of $O$. indicum promoted different LCMS chromatograms. The content of baicalin is quite stable in all flower extracts (estimated by manual observation of peak height and peak area). Baicalein and chrysin contents showed the same trends of LC-MS peaks. They are high in younger stages flowers (young buds stages 1 and 2) and they seem to decrease when the flowers are getting older (bud stages 3 and 4 which are bloom flower). Bloom flower extract showed the lowest baicalein and chrysin contents. The overall LCMS chromatogram profiles of the three major chemical constituents baicalin, baicalein, and chrysin of the pedicel extract from $O$. indicum are similar to the bloom flower extract (constant baicalin content and low amounts of baicalein and chrysin) while the content of these 3 flavonoids in the stalk extract is different. This extract contains the amount of baicalin similar to others; however, the amounts of baicalein and chrysin are higher than the yield of these two compounds in bud stage 3, bloom flower, and pedicels extracts but lower than those of bud stages 1 and 2 extracts. Moreover, there is another peak at RT 1.93 minutes with the molecular mass of 253. This compound could be a flavonoid glycoside. The LC-MS profile of the leaf extract from O. indicum is different from those of flower and whole fruit extract. The amounts of baicalin and baicalein are very low, but the amount of chrysin is high. There are other peaks at RT 1.96, 2.91 and 4.61 minutes with the molecular masses of 253,284 , and $268 \mathrm{~m} / \mathrm{z}$, respectively. These compounds could also be flavonoids. 

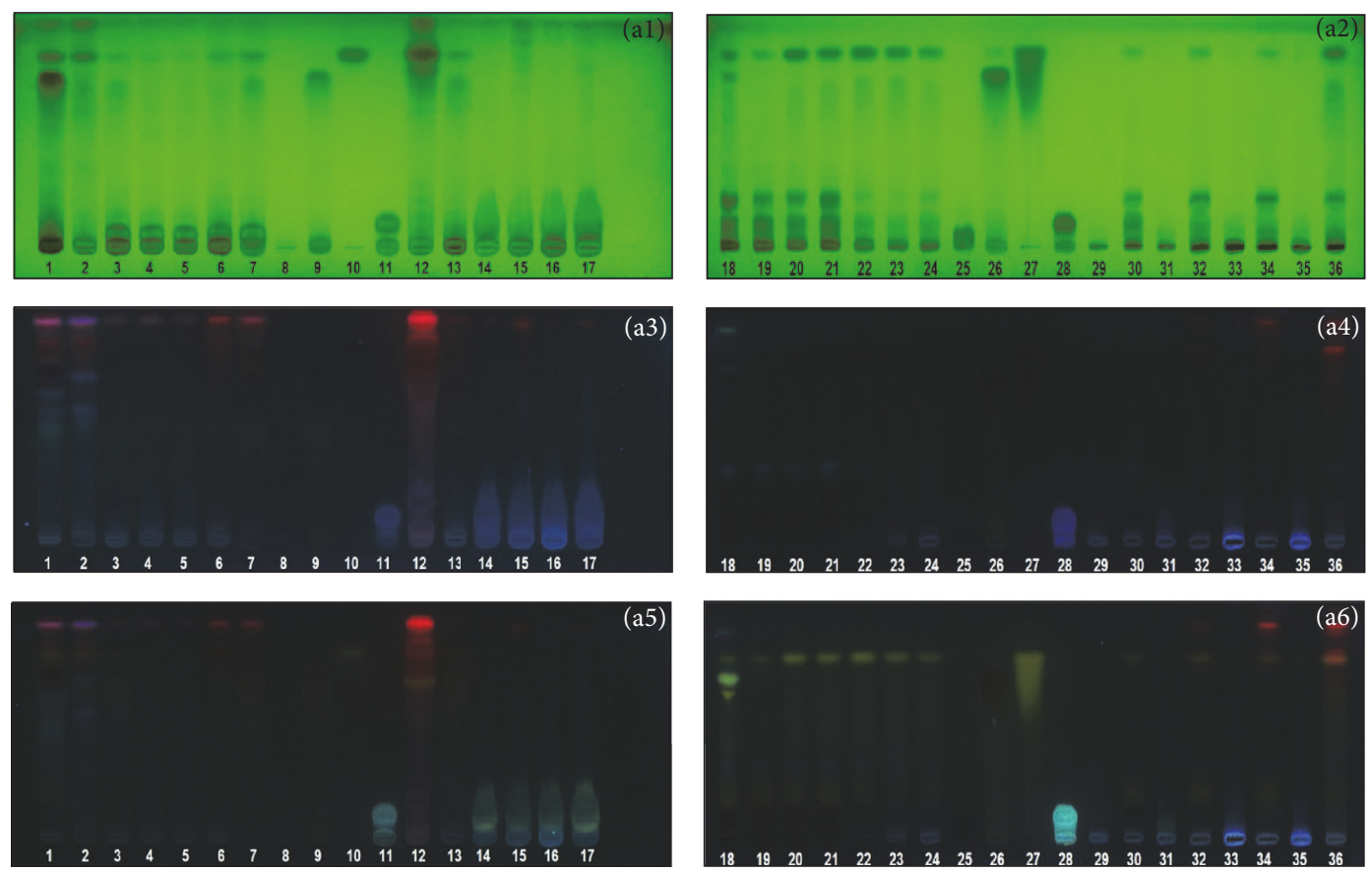

(a)


(b)

FIGURE 2: TLC chromatogram of Oroxylum indicum extracts; $1=$ OIFL1, $2=$ OIFL2, $3=$ OIFL3, $4=$ OIFL4, $5=$ OIFL4, $6=$ OIS, $7=$ OIPC, 8 = baicalin, $9=$ baicalein, $10=$ chrysin, $11=$ chlorogenic acid, $12=$ OIL, $13=$ OIWF, $14=$ OICB, $15=$ OICG, $16=$ OICW, $17=$ OICY, $18=$ OIMS, $19=$ OITPd3, $20=$ OITPd5, $21=$ OITPd7, $22=$ OITPw2, $23=$ OITPw3, $24=$ OITPw4, $25=$ baicalin, $26=$ baicalein, $27=$ chrysin, $28=$ chlorogenic acid, $29=$ OITPw5R, $30=$ OITPw5S, $31=$ OITPw6R, $32=$ OITPw6S, $33=$ OITPw7R, $34=$ OITPw7S, $35=$ OITPw8R, and 36 = OITPw8S, adsorbent: silica gel GF254. Solvent system: A = hexane-ethyl acetate-acetic acid-formic acid $(5: 5: 1: 1 v / v / v / v)$, B = toluene-ethyl acetate-formic acid $(25: 25: 7.5 \mathrm{v} / \mathrm{v} / \mathrm{v})$, detection: $1=\mathrm{UV} 254 \mathrm{~nm}, 2=\mathrm{UV} 366 \mathrm{~nm}$, and $3=\mathrm{NP} / \mathrm{PEG}$ under UV $366 \mathrm{~nm}$. Band identification system A: baicalin $(R f=0.06)$, chlorogenic acid $(R f=0.11)$, baicalein $(R f=0.64)$, and chrysin $(R f=0.71)$. Band identification system $B$ : baicalin $(\mathrm{Rf}=0.02)$, chlorogenic acid $(\mathrm{Rf}=0.11)$, baicalein $(\mathrm{Rf}=0.60)$, and chrysin $(\mathrm{Rf}=0.70)$. 
From LC-MS analysis, the amounts of baicalin, baicalein, and chrysin in the whole fruit extract are high, especially the amount of baicalin which is higher than in the other extracts. There is a peak at RT 1.96 minutes with the molecular masses of 253. This compound could be a flavonoid. The LC-MS chromatograms from extracts of 4 different colors $O$. indicum calluses showed very low intensity peaks at a concentration of $100 \mu \mathrm{g} / \mathrm{mL}$. The reason, therefore, might be different batches and ages of the calluses used in this analysis. They were different from the other calluses used in other experiments in this study. The LC-MS chromatograms of extracts from $O$. indicum and reference compounds are shown in Figure 3.

3.6. Principal Component Analysis (PCA) of Results from Oroxylum indicum Extracts. The PCA results were used to generate the projection plot (Figure 4) that provides a visual determination of the similarity among the O. indicum samples. The loading plot of $O$. indicum samples was obtained from their $\mathrm{EC}_{50}$ values from the $\mathrm{DPPH}$ scavenging assay and the total phenolic and the total flavonoid contents. Figure 4(a) shows the overall plot of $\mathrm{EC}_{50}$ values from DPPH scavenging assay and total phenolic and total flavonoid contents of $O$. indicum samples. It was found that all samples scattered in disorder pattern. However, some samples could be grouped together such as extracts from callus including brown callus (23, OICB), green callus (24, OICG), white callus $(25, \mathrm{OICW})$, yellow callus $(26, \mathrm{OICY})$ extracts from young tissue-cultured plants 5 (OITPw2) and 3 (OITPd5), extracts from flowers 17 (OIFL2), 18 (OIFL3), 19 (OIFL4), and 21 (OIS), 15 (OITPw8S) and extracts from the root of tissue-cultured plant groups 8 (OITPw5R), 10 (OITPw6R), 12 (OITPw7R), and 14 (OITPw8R). Extracts from the leaf (22, OIL) and whole fruit (27, OIWF) showed some similarities and stayed close to each other in PCA score plots as shown in Figure 4 . When the samples were grouped by total phenolic and total flavonoid contents as shown in Figure 4(b), 4 main clusters of $O$. indicum samples of callus and young tissuecultured plant group, tissue-cultured plant group, flower group, and whole fruit and leaf group could be organized. It should be mentioned that the mature seed (1, OIMS) and flower stage $1(16$, OIFL1) are localized outside the area of other samples. Figures 4(c) and 4(d) suggest the similarity of $O$. indicum samples analyzed by $\mathrm{EC}_{50}$ values from $\mathrm{DPPH}$ scavenging assay and total phenolic content and $\mathrm{EC}_{50}$ values from DPPH scavenging assay and total flavonoid content, respectively. Similar trends were found in both plots; all O. indicum samples could be grouped together except the extracts from the root of tissue-cultured plants 8 (OITPw5R), 10 (OITPw6R), 12 (OITPw7R), and 14 (OITPw8R) which clearly separated from the rest of the samples.

This research is the first report of phytochemical profiles determined by TLC and LC-MS methods and in vitro antioxidant activities tested by the DPPH scavenging assay of extracts from different origins of $O$. indicum including raw materials from different plant parts (seeds, whole fruits, flowers, leaves, pedicels, and stalks), tissue-cultured plants from different growth stages, and callus cultures. Extracts from stalk, pedicel, bloom flower (flower stage 4), bud (flower stage 1), and calluses exhibited high antioxidant effects.
Baicalin and baicalein which are present in most extracts showed high antioxidant effects while chrysin which is a major flavonoid in the leaves and tissue-cultured plants promoted very low antioxidant activity. This suggests that there are other compounds responsible for the antioxidant activities of $\mathrm{O}$. indicum. Some flavones and their glycosides such as scutellarein, norwogonin, acacetin, hispidulin, oroxylin A, apigenin, and tetuin were previously reported in the leaves, seeds, stem bark, and root bark of $O$. indicum [15-20]. Flavonols, flavonoids with a hydroxyl group at the C-3 position, were reported to promote better antioxidant effect than other flavonoids without this functional group such as flavones [21]. Some flavonols previously reported in O. indicum including kaempferol and quercetin could also support the antioxidant effect of this plant [22]. There were studies about in vitro propagation by callus and shoot induction [23-26] and protoplast isolation [27] for the production of $O$. indicum. Auxin and cytokinin were reported as good growth regulators for $O$. indicum callus induction [28]. The recent study indicated that GA3 had a significant effect on seed germination of $O$. indicum. Moreover, total phenolic and total flavonoid contents were reported to be maximum in in vitro developed root compared to other in vitro plant parts [29]. Another report indicated the presences of baicalein and chrysin in callus extracts of O. indicum [30].

\section{Conclusion}

From all of the results, it could be summarized that the stalk, pedicel, flowers, seeds, fruits, and callus promoted the extract with high antioxidant activity and contained high total phenolic and total flavonoid contents with baicalin, baicalein, and chrysin as main ingredients found in these extracts. The shoot extracts from tissue-cultured plants also promoted some antioxidant effects but their contents of phenolics and flavonoids are quite low. Mature seeds, buds (flowers stage 1), blossoms (flowers stage 4), stalks, and leaves are interesting plant parts which should be further investigated for other active ingredients. Biotechnological studies should be provided for more research about callus and tissue-cultured plant material, especially the callus cultures which promoted a strong antioxidant effect and a high total phenolic content.

\section{Conflicts of Interest}

All authors declare no conflicts of interest with the trademarks included in the paper.

\section{Acknowledgments}

The authors would like to thank Dr. Karin ArdjomandWoelkart, Institute of Pharmaceutical Sciences, Pharmacognosy, University of Graz, for her guidance and help with the LC-MS. ASEA UNINET is acknowledged for providing scholarships to Piyanuch Rojsanga and Pongtip Sithisarn. The authors also would like to thank the Faculty of Pharmacy, Mahidol University, Center of Excellence in Herbal Medicine and Natural Products, the Office of the High Education 


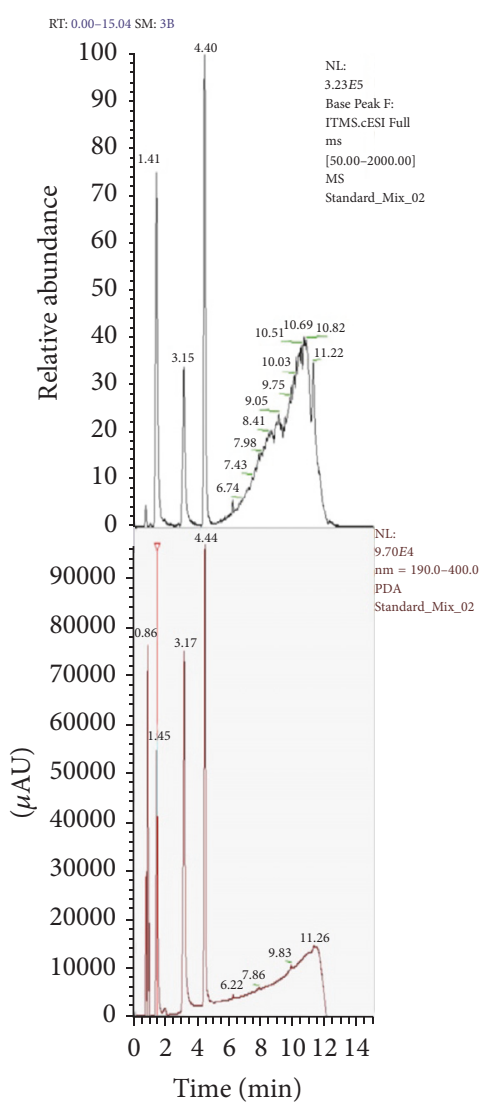

(a)

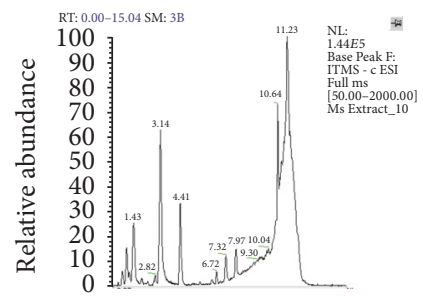

(e)
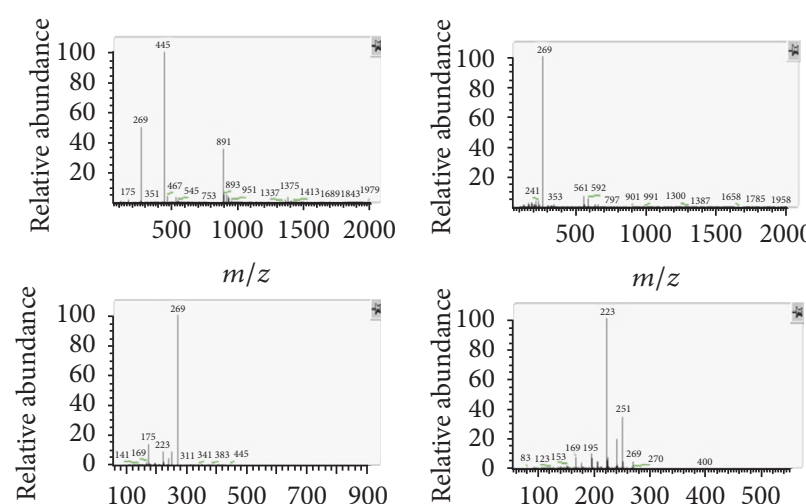

$\mathrm{m} / \mathrm{z}$
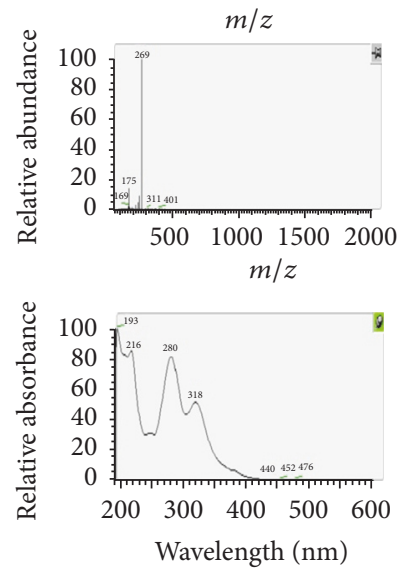

(b)

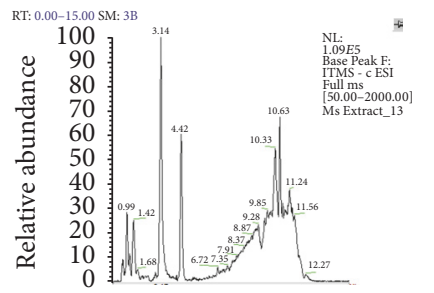

(f)

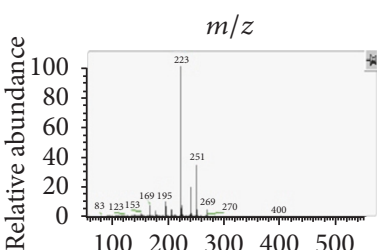

$m / z$

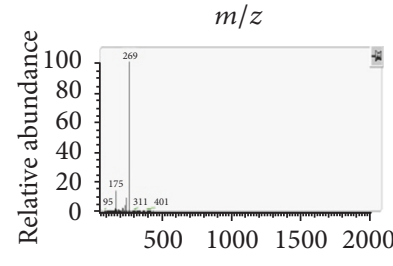

$m / z$

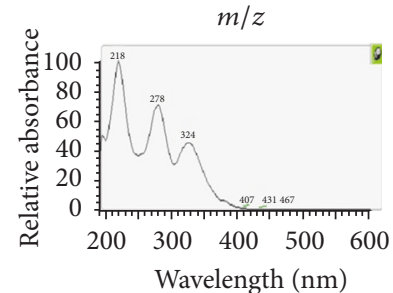

(c)

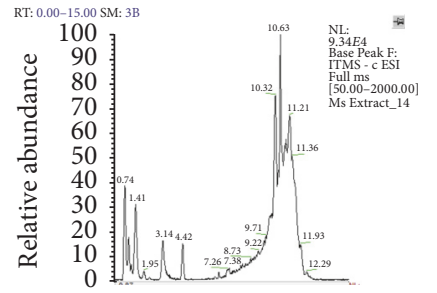

(g)

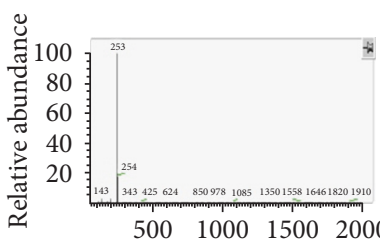

$m / z$

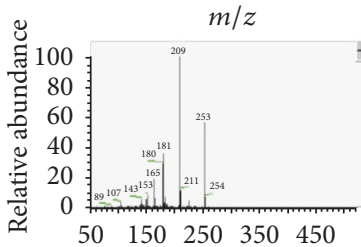

$m / z$

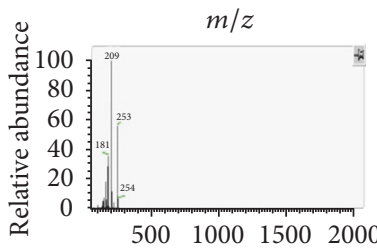

$m / z$

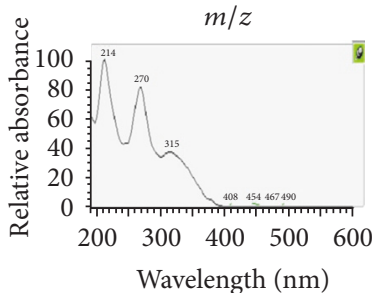

(d)

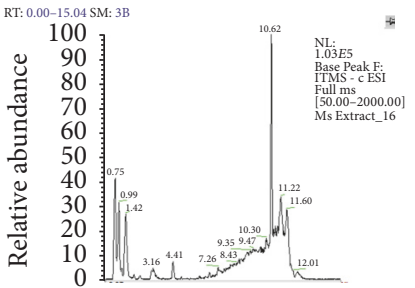

(h)

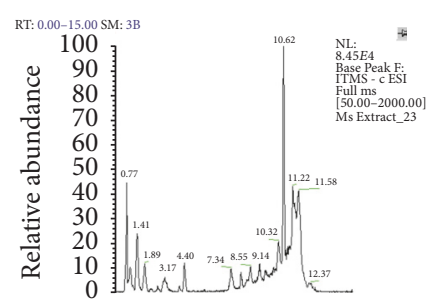

(i)

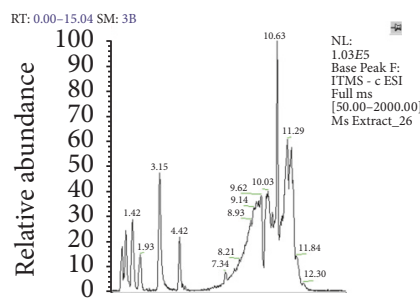

(j)

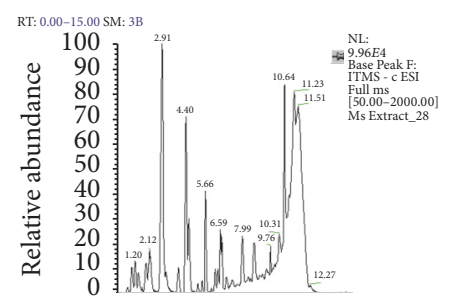

$(\mathrm{k})$

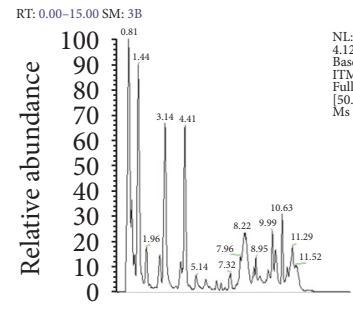

(1)
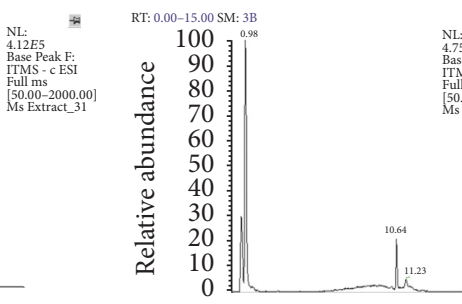

(m)

FIGURE 3: LC-MS chromatograms of Oroxylum indicum extracts; (a) = mixtures of reference compounds, (b) = mass spectra and UV spectra of baicalin, (c) = mass spectra and UV spectra of baicalein, $(\mathrm{d})=$ mass spectra and UV spectra of chrysin, $(\mathrm{e})=$ flower stage 1 extract, $(\mathrm{f})=$ flower stage 2 extract, $(\mathrm{g})=$ flower stage 3 extract, $(\mathrm{h})=$ flower stage 4 extract, $(\mathrm{i})=$ pedicel extract, $(\mathrm{j})=$ stalk extract, $(\mathrm{k})=$ leaf extract, $(\mathrm{l})=$ whole fruit extract, and $(\mathrm{m})=$ callus extract. 


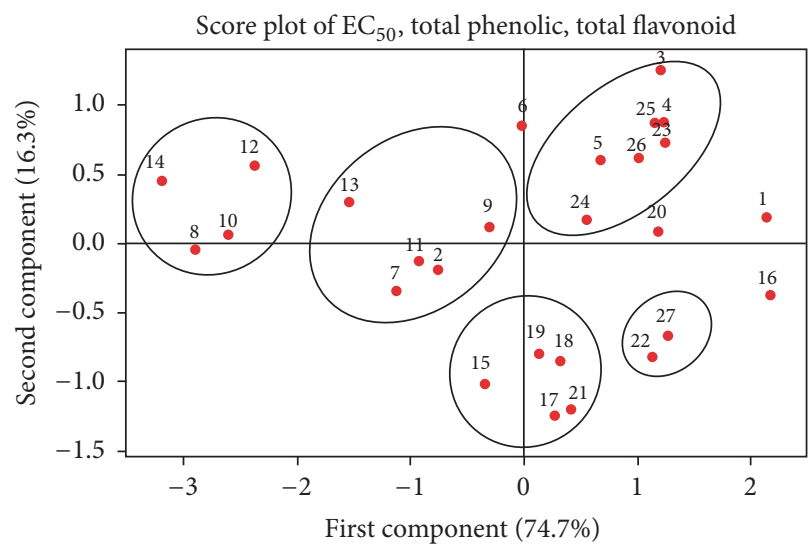

(a)

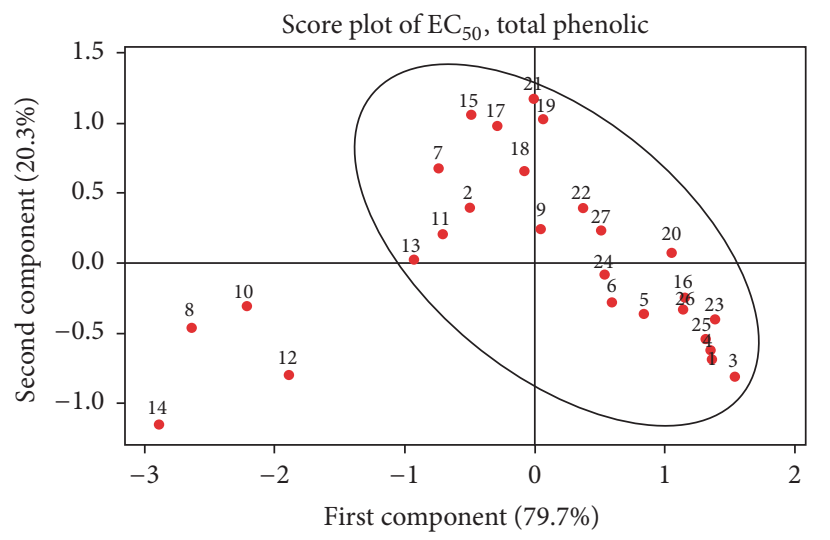

(c)

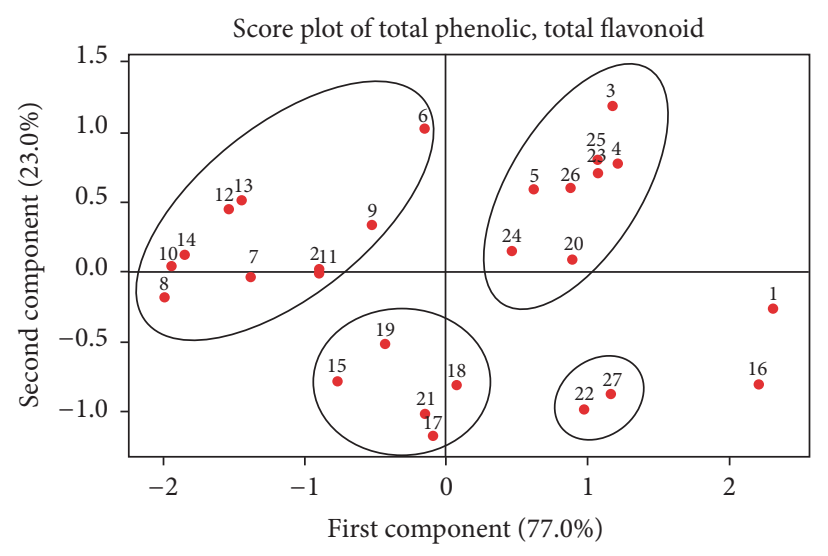

(b)

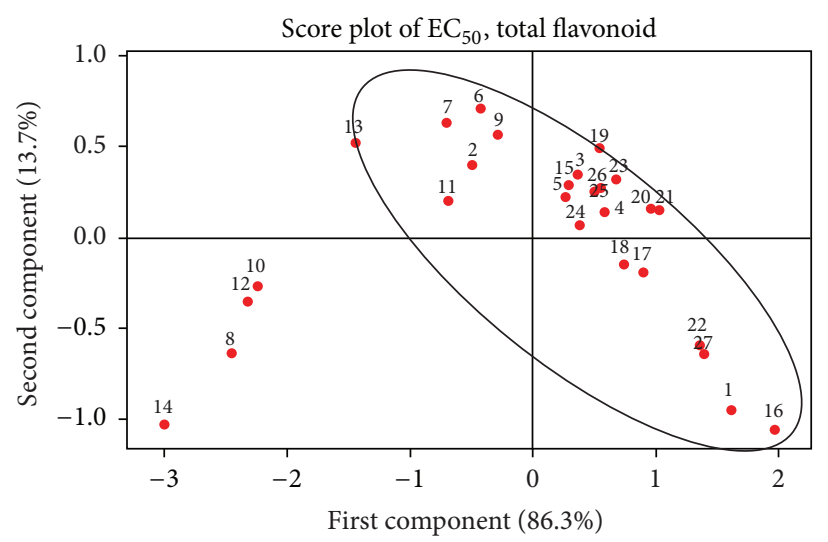

(d)

FIGURE 4: Score plot of principal component scores obtained from $\mathrm{EC}_{50}$ values from DPPH scavenging assay, total phenolic and total flavonoid contents of $\mathrm{O}$. indicum extracts from various plant parts, and growth stages as shown in Table $1.1=\mathrm{OIMS}, 2=\mathrm{OITPd} 3,3=\mathrm{OITPd} 5,4=$ OITPd7, 5 = OITPw2, 6 = OITPw3, $7=$ OITPw4, $8=$ OITPw5R, $9=$ OITPw5S, $10=$ OITPw6R, $11=$ OITPw6S, $12=$ OITPw7R, $13=$ OITPw7S, $14=$ OITPw8R, $15=$ OITPw8S, $16=$ OIFL1, $17=$ OIFL2, $18=$ OIFL3, $19=$ OIFL4, $20=$ OIPC, $21=$ OIS, $22=$ OIL, $23=$ OICB, $24=$ OICG, 25 $=\mathrm{OICW}, 26=\mathrm{OICY}$, and $27=\mathrm{OIWF}$.

Commission, and Mahidol University, under the National Research Universities Initiative for their financial support.

\section{References}

[1] P. K. Warrier, V. P. K. Nambiar, and C. Ramankutty, "Indian medicinal plant: a compendium of 500 species," Orient Longman, vol. 4, pp. 186-290, 1993.

[2] S. N. Chauhan, "Medicinal and aromatic plants of Himachal Pradesh," Indus publishing, pp. 296-298, 1999.

[3] Harminder, V. Singh, and A. K. Chaudhary, "A review on the taxonomy, ethnobotany, chemistry and pharmacology of Oroxylum indicum vent," Indian Journal of Pharmaceutical Sciences, vol. 73, no. 5, pp. 483-490, 2011.

[4] P. Sithisarn, P. Nantateerapong, P. Rojsanga, and P. Sithisarn, "Screening for Antibacterial and Antioxidant Activities and Phytochemical Analysis of Oroxylum indicum Fruit Extracts," Molecules, vol. 21, no. 4, article no. 446, 2016.

[5] A. K. Bhattacharjee and A. K. Das, "Phytochemical Screening of Some Indian Plants," Quarterly Journal of Crude Drug Research, vol. 9, no. 3, pp. 1408-1412, 2008.
[6] L.-J. Chen, D. E. Games, and J. Jones, "Isolation and identification of four flavonoid constituents from the seeds of Oroxylum indicum by high-speed counter-current chromatography," Journal of Chromatography A, vol. 988, no. 1, pp. 95-105, 2003.

[7] L. J. Chen, H. Song, X. Q. Lan, D. E. Games, and I. A. Sutherland, "Comparison of high-speed counter-current chromatography instruments for the separation of the extracts of the seeds of Oroxylum indicum," Journal of Chromatography A, vol. 1063, no. 1-2, pp. 241-245, 2005.

[8] J. Gago, O. Pérez-Tornero, M. Landín, L. Burgos, and P. P. Gallego, "Improving knowledge of plant tissue culture and media formulation by neurofuzzy logic: A practical case of data mining using apricot databases," Journal of Plant Physiology, vol. 168, no. 15, pp. 1858-1865, 2011.

[9] S. Gonda, A. Kiss-Szikszai, Z. Szucs, C. Máthé, and G. Vasas, "Effects of $\mathrm{N}$ source concentration and $\mathrm{NH} 4+/ \mathrm{NO} 3$ - ratio on phenylethanoid glycoside pattern in tissue cultures of Plantago lanceolata L.: A metabolomics driven full-factorial experiment with LC-ESI-MS3," Phytochemistry, vol. 106, pp. 44-54, 2014.

[10] T. Murashige and F. Skoog, "A revised medium for rapid growth and bioassay with tobacco tissue culture," Plant Physiology, vol. 15, pp. 473-497, 1962. 
[11] P. Sithisarn, R. Supabphol, and W. Gritsanapan, "Comparison of free radical scavenging activity of Siamese neem tree (Azadirachta indica A. Juss var. siamensis Valeton) leaf extracts prepared by different methods of extraction," Medical Principles and Practice, vol. 15, no. 3, pp. 219-222, 2006.

[12] V. Naithani, S. Nair, and P. Kakkar, "Decline in antioxidant capacity of Indian herbal teas during storage and its relation to phenolic content," Food Research International, vol. 39, no. 2, pp. 176-181, 2006.

[13] A. Meda, C. E. Lamien, M. Romito, J. Millogo, and O. G. Nacoulma, "Determination of the total phenolic, flavonoid and proline contents in Burkina Fasan honey, as well as their radical scavenging activity," Food Chemistry, vol. 91, no. 3, pp. 571-577, 2005.

[14] A. Krüger and M. Ganzera, "Oroxylum indicum seeds - Analysis of flavonoids by HPLC-MS," Journal of Pharmaceutical and Biomedical Analysis, vol. 70, pp. 553-56, 2012.

[15] S. Sankara Subramanian and A. G. R. Nair, "Flavonoids of the leaves of Oroxylum indicum and Pajanelia longifolia," Phytochemistry, vol. 11, no. 1, pp. 439-440, 1972.

[16] Y. Yuan, W. Hou, M. Tang et al., "Separation of flavonoids from the leaves of Oroxylum indicum by HSCCC," Chromatographia, vol. 68, no. 11-12, pp. 885-892, 2008.

[17] J. Wen, Q. Zhang, Z. Yin, and et al, "Flavonoids from the seeds of Oroxylum indicum (L.) Vent," Zhongguo Yaoxue Zazhi, vol. 46, pp. 170-173, 2011.

[18] R.-Y. Yan, Y.-Y. Cao, C.-Y. Chen et al., "Antioxidant flavonoids from the seed of Oroxylum indicum," Fitoterapia, vol. 82, no. 6, pp. 841-848, 2011.

[19] T. Hari Babu, K. Manjulatha, G. Suresh Kumar et al., "Gastroprotective flavonoid constituents from Oroxylum indicum Vent.," Bioorganic \& Medicinal Chemistry Letters, vol. 20, no. 1, pp. 117-120, 2010.

[20] B. Dinda, I. Silsarma, M. Dinda, and P. Rudrapaul, "Oroxylum indicum (L.) Kurz, an important Asian traditional medicine: from traditional uses to scientific data for its commercial exploitation," Journal of Ethnopharmacology, vol. 161, pp. 255278, 2015.

[21] K. T. Basu, Antioxidants in human health and disease, CABI publishing, Alberta, 1999.

[22] X.-N. Wei, B.-B. Lin, G.-Y. Xie, J.-W. Li, and M.-J. Qin, “Chemical constitunents of seeds of Oroxylum indicum," Zhongguo Zhongyao Zazhi, vol. 38, no. 2, pp. 204-207, 2013.

[23] S. Tiwari, K. Singh, and P. Shah, "In vitro propagation of Oroxylum indicum-an endangered medicinal tree," Biotechnology, vol. 6, no. 2, pp. 299-301, 2007.

[24] S. Talari, S. Rudroju, and R. Nanna, "Conservation of an endangered medicinal forest tree Oroxylum indicum (L) kurz through in-vitro micropropagation-a review," European Journal of Medicinal Plants, vol. 17, no. 2, pp. 1-13, 2016.

[25] M. Gokhale and Y. K. Bansal, "Direct in vitro regeneration of a medicinal tree Oroxylum indicum (L.) Vent. through tissue culture," African Journal of Biotechnology, vol. 8, no. 16, pp. 3777-3781, 2009.

[26] N. V. Dalal and V. R. Rai, "In vitro propagation of Oroxylum indicum Vent. a medicinally important forest tree," Journal of Forest Research, vol. 9, no. 1, pp. 61-65, 2004.

[27] G. Xiuyan, J. Zhengwu, and M. Guojin, "Property evaluation of various lignocellulosic fibers from waste paper," Journal of Harbin Engineering University, vol. 36, no. 2, pp. 1-5, 2015.
[28] E. Rami and I. Patel, "Effect of growth regulators and explant types on callus induction from Oroxylum indicum (L.) Vent," Life Science, vol. 1, no. 12, pp. 278-280, 2014.

[29] E. Rami and I. Patel, "Quantitative analysis of total phenols and flavonoids in in vivo and in vitro samples of oroxylum indicum (L.) Vent," Asian Journal of Pharmaceutical and Clinical Research, vol. 8, no. 2, pp. 202-204, 2015.

[30] M. Gokhale, Y. Bansal, and S. Sandhu, "Optimization of baicalein and chrysin production in cell cultures of," Analytical Chemistry Letters, vol. 6, no. 6, pp. 834-849, 2017. 


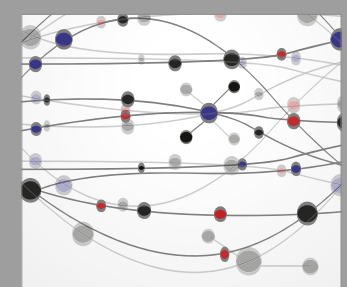

The Scientific World Journal
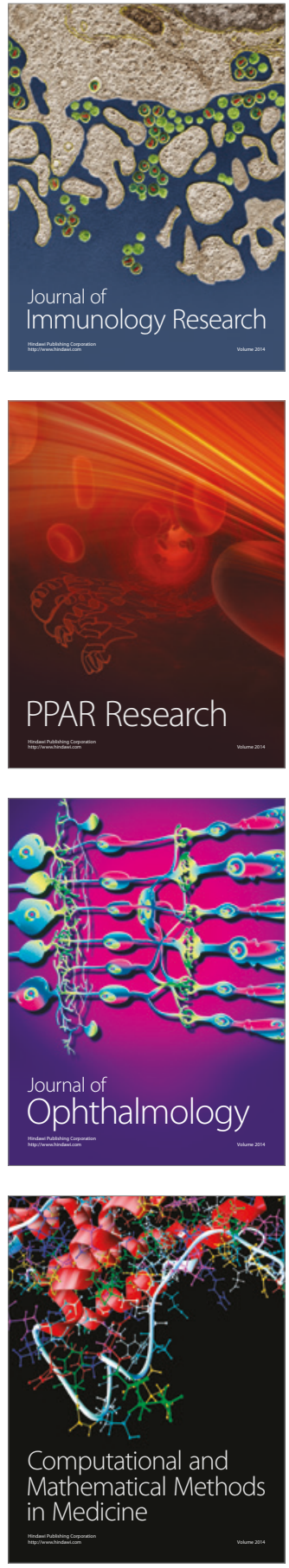

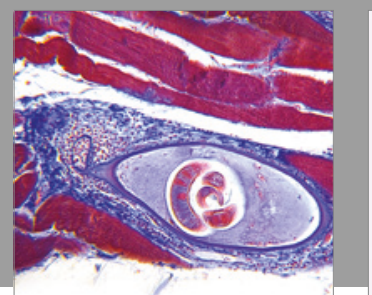

Gastroenterology Research and Practice
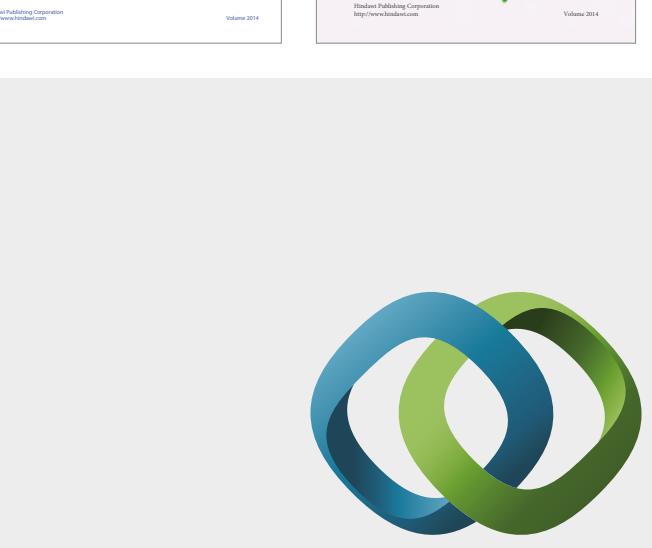

\section{Hindawi}

Submit your manuscripts at

https://www.hindawi.com
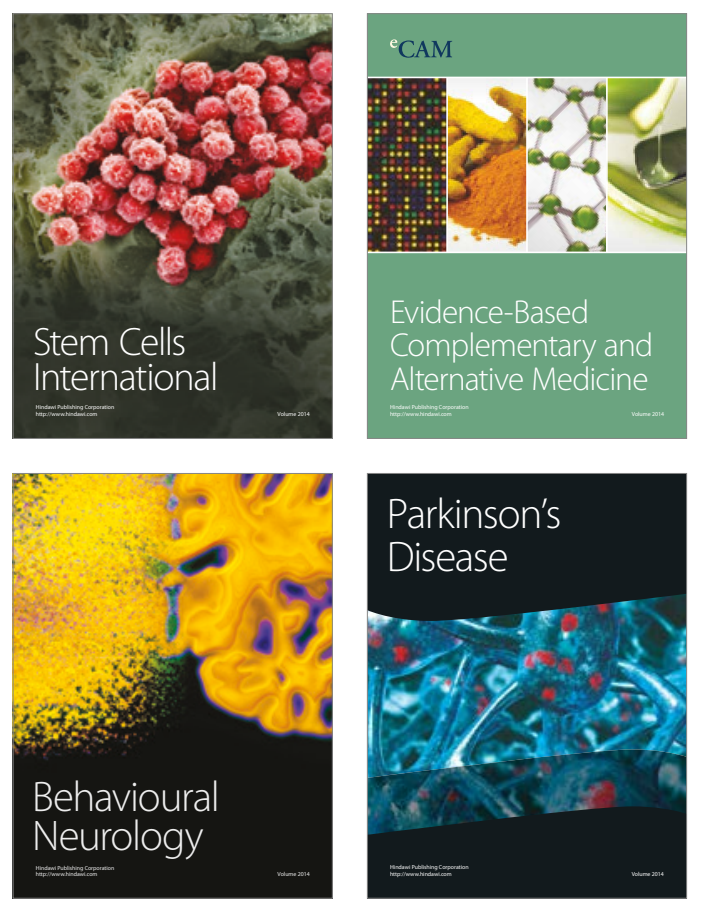
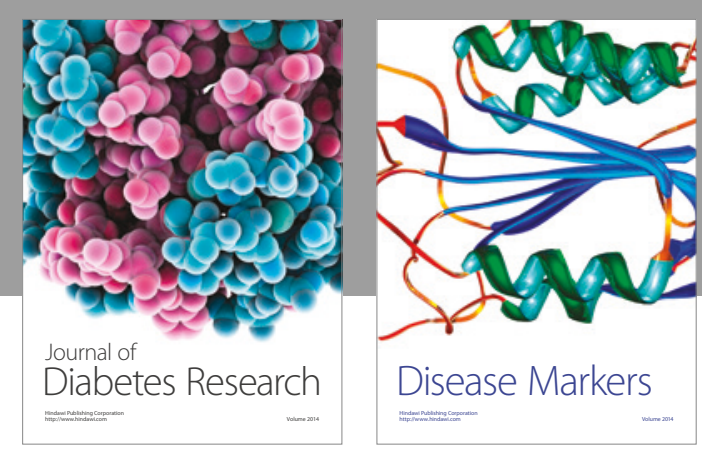

Disease Markers
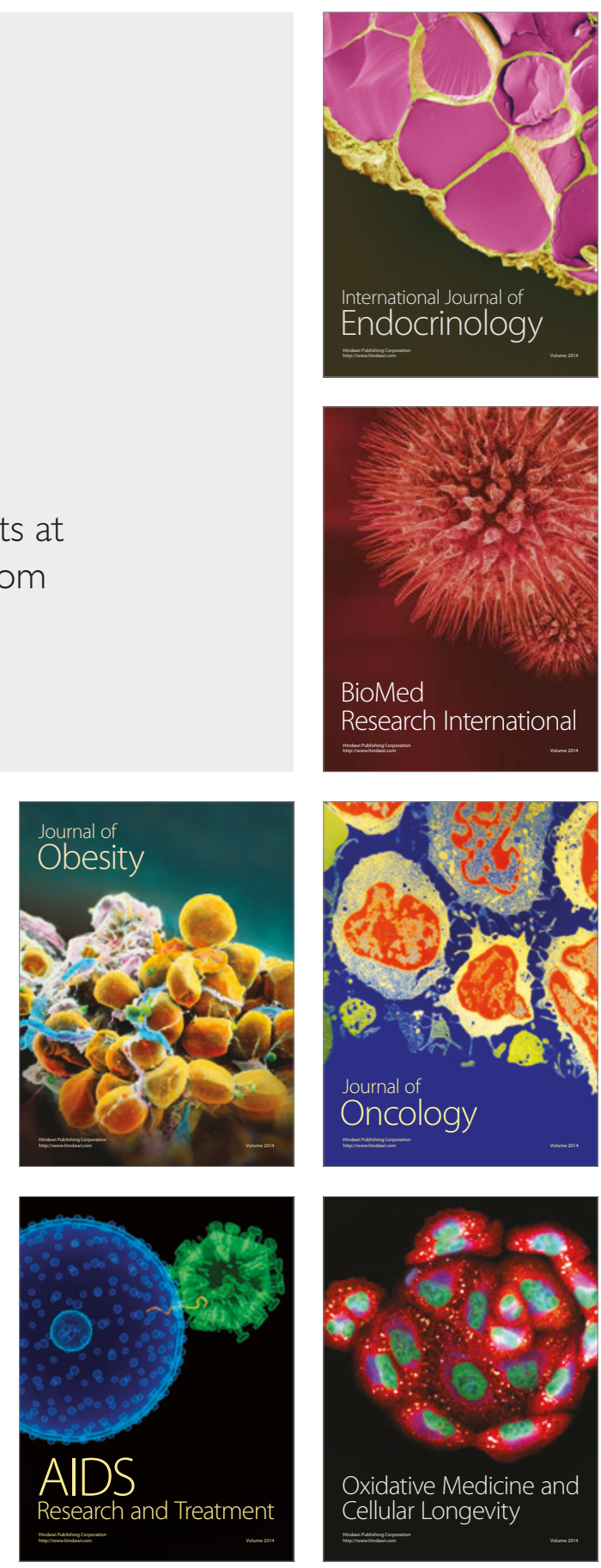